\title{
Tourists' Satisfaction and Loyalty to Tourism Product of Ardabil City: Emphasizing on Demographic and Social Characteristics
}

\author{
By Abolfazl Ghanbri* \\ Robab Naghizadeh \\ Nasrin Omrani ${ }^{*}$
}

The tourism industry requires that people have enough awareness of issues and factors affecting the economic, social and cultural aspects in each region. Thus, an effective factor on all elements of development, more than ever, needs to be studied. In tourism literature, satisfaction and loyalty to the tourism product based on socio-demographics has never been analyzed and discussed. The purpose of this study is to evaluate tourists' satisfaction and loyalty to tourism products, such as attractions and facilities, based on socio-demographic factors (gender, age, education level, marital, and occupation). In order to assess tourists' satisfaction with Ardebil city, a tourism product questionnaire was used as a survey instrument. The validity and reliability of the survey was based on content validity of Cronbach's Alpha value in SPSS software Version 24, the amount of which is estimated to be $85 \%$. On the whole, 384 questionnaires were distributed through a sampling method among tourists in the summer of 2016 in the township of Ardebil. The results indicated that tourists experienced different levels of satisfaction with the tourism products of Ardabil city. Analysis of the results also showed that there is a relationship between socio-demographic factors and tourists' loyalty.

Keywords: Tourist, satisfaction, Ardabil city, Tourist loyalty, Socio-demographic characteristics.

\section{Introduction}

During the past half century, tourism activities have become widespread, and each year the number of passengers, who travel for a variety of motives, is increasing (Eftekhari et al. 2011: 23). Tourism is thus an important part of the economic sector (Lopes 2011: 306), and it is an activity that has many social and cultural influences in addition to its economic and employment benefits (Hazar Jaberi and Najafi 2012: 134).

In addition to this general increase in global tourism, Iran also has the benefit of being one of the most spectacular countries in the world. Therefore, our country is one of the top 10 countries in terms of tourism attractions (cultural), one of the first five countries in the world in terms of tourism diversity (regarding the natural environment), and is one of the first three countries in the world in terms of handicrafts (Zangi Abadi et al. 2006: 131). Iran has such great potential for

\footnotetext{
*Associate Professor, Department of Geographical Research, University of Tabriz, Iran.

${ }^{\dagger}$ MSc. in Geography and Tourism Planning, University of Tabriz, Iran.

${ }^{\star}$ MSc. Student in Economical Sciences, University of Tabriz, Iran.
} 
tourism because it is the eighteenth largest country in the world in terms of area. It is located in the southwestern area of Asia and covers land area of more than $1,648,000 \mathrm{~km}^{2}$. Moreover, a review of 3167 tourist attractions found that Iran is rich in cultural and natural tourism resources, many of which are unique in the world (Zeinali et al. 2014: 68).

Tourism has become one of the important sectors of the global economy accounting for $11 \%$ of global gross domestic product (GDP) and employing 200 million people. In Iran, tourism is estimated to account for $5.6 \%$ of the country's total GDP, $5.1 \%$ of the country's total employment, $2.9 \%$ of the country's total capital investments, and $2.8 \%$ of the country's total exports (WTTC 2013). However, tourism in Iran faces eight considerable challenges: (1) global competition in the growing tourism industry; (2) an economic system that traditionally does not emphasize the quality of services and products; (3) a high level of contradiction in the tourists' decisions; (4) low accessibility to destinations; (5) lack of systematic maintenance of tourism attractions; (6) a low level of creativity of tour operators, authorities and decision makers; (7) lack of marketing programs; and (8) short-term economy investments (Zainli and Goujali 2015: 68).

Ardabil is located in a vast plain, $45 \mathrm{~km}$ long, on the slopes of Mount Sabalan. The weather in Ardabil city is moderate and cool in spring and summer. Handicrafts and souvenirs from the region include Glim, Jajim, Shal, Varni, Masnad, Pottery, Wood Industries, Leather and Carpet artifacts, and its other souvenirs are honey, black halva and local sweets. Historic monuments and tourist attractions of the city include the monument of Sheikh Safiuddin Ardabili, a monument related to the Ilkhani-Safavi era, the Ardabil indoor arena with arched vaulted ceilings, Mirza Ali Akbar mosque related to the Qajar period, the Friday mosque belonging to the Saljoughi period, the Shorabil Tourist Complex, Neur Sea Lake, $48 \mathrm{~km}$ south-east of Ardabil, warm water and Sardabeh waterfall, Shatar Gonbadi Tower in Soma Village, Sheikh Gabriel Tomb, Sheikh Safiuddin Ardabili's father in Kalkhoran neighborhood (Cultural Heritage, Handicrafts and Tourism Organization of Ardabil Province 2016). Given that a comprehensive research on the impact of demographic characteristics on the satisfaction of tourists in Iran has not been done, especially in the Ardabil province, the need for this research is felt very strongly. Therefore, the main objective of this research is to find the effect of demographic characteristics on tourism satisfaction in Ardabil city. In this regard, the hypotheses considered are as follows:

$\mathrm{H}_{1}$ Tourists experienced different levels of satisfaction based on demographic characteristics (age, gender, marriage, education, employment) from the tourism products of Ardabil.

$\mathrm{H}_{2}$ Demographic and social characteristics are influential on the future behavioral habits of tourists. 


\section{Tourism Satisfaction, Demographics and Social Features}

Tourist satisfaction is obtained when the appropriate processes are designed in such a way that the services provided meet the expectations of the tourist (Gholipoor and Rashidi 2008: 3). Satisfaction of the tourist plays an important role in the success of the tourism destination's marketing, because it influences the choice of destination, the consumption of tourism goods and services, and the decision to return to the destination (Yoon and Uysal 2003: 47).

Bardin (1977) divides 33 elements of tourism satisfaction into five major groups:

- Access, including road conditions.

- Costs, including tolls and fuel or tickets, accommodation, food, recreation and entertainment.

- Natural attractions.

- Artificial attractions, including bars, restaurants, shopping malls, cinemas, artworks, art and religion.

- Infrastructure, including housing, access to information, communications, roads, health and safety (Oliveira 2011: 235).

Kotler (1999) was the pioneer in developing the term "customer satisfaction" in the business and marketing sectors (Forozia et al. 2013: 4332). He states that discontent occurs when customers experience significant differences between their expectations and the quality of services they receive (Forozia et al. 2013: 4333).

Demographic characteristics are some of the main factors for assessing the satisfaction of tourists. Thus, with a survey of market segmentation, five social and demographic dimensions are chosen (Zeinali et al. 2014: 69). These are as follows. First, gender is an aspect of demographic features that seems to be important in tourism research (Schofield and Thompson 2007: 329). For example, Perovick et al. (2012) showed that gender had no effect on the level of satisfaction of tourists in Montenegro. Zainli and Goujali (2015) concluded that gender had a different impact on tourists' satisfaction with the services of beach vacation villas of the ages. The second is age, which is another aspect of demographic characteristics considered to be indicative of physical fitness, level of activity, attachments and interests, and previous travel experience (Pearce 2005: 28). Some researchers have examined the relationship between age and tourist satisfaction levels. For example, Perovick et al. (2012) examined the effect of age on the level of satisfaction of tourists in Montenegro and concluded that age had no effect on the satisfaction of tourists. Third, it is clear that a higher level of education increases a person's travel tendencies and number of trips (Zeinali et al. 2014:17). Therefore, some researchers have examined the effect of level of education on the satisfaction of tourists. For example, Mellina and Aballe (2013) found significant difference in the level of satisfaction of tourists based on their level of education. Tsiotsou and Vasiotio (2006) showed that level of education can differentiate between two groups of tourists (very satisfied and less satisfied). Marital status is another demographic variable that can have a different effect on the level of satisfaction of 
tourists. Finally, some researchers have shown that employment can affect perceptions of time, level of satisfaction and travel experience (Zeinali et al. 2014: 70).

\section{Literature Review}

Ebrahimzadeh and Vlashejordi Farahani (2012) in a paper titled "An Analysis of the Motives of Tourists and the Impact of the Gender and Income on it" (Case Study, Nowruz Tourists in Mahallat County) present research findings from 185 questionnaires that were analyzed by factor analysis to identify the motivations of respondents. They used T-test and one-way variance tests for the analysis of the hypotheses in order to identify the motivations. The results indicate that only four factors in the incentives of tourists can explain $1.58 \%$ of the variance of the studied items and reaches more than $90 \%$ with consideration of other factors. Among them, the relaxation factor and recreation have the highest percentage of variances. The results of the hypothesis test also indicated a significant difference in income between the motivational types of tourists.

Aminbaydokhty and Rohipour (2013) studied the effect of demographic characteristics on customers' expectations of services in the hospitality industry of Semnan province. The LADJSRO index is used to measure the quality of services. To analyze the data, factor analysis was used to reduce 26 questions to 5 dimensions of service quality; multivariate analysis of variance was used to study the effect of demographic characteristics on five dimensions of service quality and test the hypotheses. The results showed that age is the only demographic characteristic that affects customer expectations of five dimensions of service quality, while the demographic characteristics of gender, marital status, income, and educational level have no effect on customer expectations of the quality of services.

Zeinali et al. (2014), in an article on socio-demographic analysis of the satisfaction and loyalty of tourists at the Park of Eil Goli in Tabriz, showed that tourists received different levels of satisfaction from access and park stores. Factors affecting satisfaction were attractiveness, safety, respectful behavior of vendors, convenience of public transport, parking facilities and transportation costs. The results also indicated that age and income are not related to the satisfaction of tourists, but ultimately the level of education affects the decision to return to the destination.

Jabari et al. (2016) reviewed the role of demographic variables in the opinions of medical tourists regarding the quality of hospital services. This descriptiveanalytical study was performed on 200 foreign patients referred to Shiraz Hospital in 2012-2013. The data collection tool was a questionnaire. Data were analyzed by an independent t-test and one-way ANOVA using SPSS software. The results of this study showed that the age group over 50 years old was more than $26 \%$, but was lower than the other two age groups. 


\section{Research Methodology}

In this research, the city of Ardabil is considered as a tourist destination. This study consists of three parts. The first part collects information about the tourist's profile. In order to determine the tourist profile of Ardabil city, the questions focused on social and demographic characteristics. Socio-demographic features include gender, marital status, educational level, age, and employment. Travel features include information sources, length of stay, residence, number of visits, and transportation. The second part of the questionnaire measures the level of satisfaction of tourists with the quality of tourism services in Ardabil city. Various options to measure the satisfaction of tourists on a five point scale. The third section examined the loyalty of tourists to the destination, as shown through the the decision to return to the destination. These data were evaluated using SPSS software version 24. The results of the Kolomographer-Smirnov test revealed the abnormal results of the research data. Non-parametric tests have been used for non-normalization of data. Therefore, the most appropriate test to measure the nominal variables is a chi-square test.

\section{Research Findings}

In total, 384 questionnaires were distributed among tourists. After collection, 360 questionnaires were used to assess and measure the opinions. In terms of gender, $55.3 \%$ of the respondents were men and $44.7 \%$ were women. In terms of age, $16.7 \%$ (a frequency of 60 ) were under 20 years old; $24.7 \%$ (89) between 20 and 29 years; $30.3 \%$ (109) between 30 and 39 years; $11.9 \%$ (43) between 40 and 49 years old; $8.1 \%$ (29) between 50 and 59 years, and $8.3 \%$ (30) over 60 years of age. In terms of marital status, $41.1 \%$ (148) were single, while $58.9 \%$ (212) were married. According to the level of education, $18.9 \%$ (68) had attended primary school only; $15.3 \%$ (55) had a high school degree; 9.7\% (35) had taken some university courses; $38.6 \%$ (139) had a university degree; and finally, $17.5 \%$ (with a frequency of 63) had either a master's degree or PhD (Table 1). Regarding employment, we divided the studied population into several subgroups of specialists, employees, self-employed persons, workers, unemployed, collegians and students. The frequency distribution of the statistical sample according to the type of occupation in Table 1 shows that $5.6 \%$ (20) were specialists; $19.4 \%$ (70) were employees; $23.3 \%(84)$ had free occupation, those who are not government employees); $2.2 \%$ (8) were workers, $21.4 \%$ (77) were unemployed; and $28.1 \%$ (101) were collegians and students. 
Table 1. Socio-demographic Characteristics of Tourists

\begin{tabular}{|c|c|c|c|c|c|c|c|}
\hline \multicolumn{2}{|c|}{ Gender } & \multicolumn{2}{c|}{ Level of Education } & \multicolumn{2}{c|}{ Age } & \multicolumn{2}{c|}{ Employment } \\
\hline Men & $55.3 \%$ & $\begin{array}{c}\text { Primary } \\
\text { school only }\end{array}$ & $18.9 \%$ & $<20$ & $16.7 \%$ & Specialists & $5.6 \%$ \\
\hline Women & $44.7 \%$ & $\begin{array}{c}\text { High School } \\
\text { degree }\end{array}$ & $15.3 \%$ & $20-29$ & $24.7 \%$ & Employees & $19.4 \%$ \\
\hline Marital status & $\begin{array}{c}\text { University } \\
\text { Courses }\end{array}$ & $9.7 \%$ & $30-39$ & $30.3 \%$ & $\begin{array}{c}\text { Free } \\
\text { occupation }\end{array}$ & $23.3 \%$ \\
\hline Single & $41.1 \%$ & $\begin{array}{c}\text { University } \\
\text { degree }\end{array}$ & $38.6 \%$ & $40-49$ & $11.9 \%$ & Workers & $2.2 \%$ \\
\hline Married & $58.9 \%$ & $\begin{array}{c}\text { Master's and } \\
\text { Ph.D. }\end{array}$ & $17.5 \%$ & $50-59$ & $8.1 \%$ & Unemployed & $21.4 \%$ \\
\cline { 5 - 8 } & & & $>60$ & $8.3 \%$ & Students & $28.1 \%$ \\
\hline
\end{tabular}

Table 2. Tourists Tour Profile

\begin{tabular}{|c|c|c|c|c|c|c|c|}
\hline \multirow{6}{*}{$\begin{array}{c}\text { Source of } \\
\text { information }\end{array}$} & \multicolumn{2}{|c|}{ TV } & $27.2 \%$ & \multirow{6}{*}{$\begin{array}{c}\text { Number of } \\
\text { trips }\end{array}$} & \multirow{2}{*}{ First time } & & \\
\hline & \multirow{2}{*}{\multicolumn{2}{|c|}{ Newspapers }} & & & & & \\
\hline & & & & & \multirow{2}{*}{\multicolumn{2}{|c|}{ Second time }} & \multirow[b]{2}{*}{$0.45 \%$} \\
\hline & \multicolumn{2}{|c|}{$\begin{array}{c}\text { Friends and } \\
\text { acquaintances }\end{array}$} & $34.7 \%$ & & & & \\
\hline & \multirow{2}{*}{\multicolumn{2}{|c|}{$\begin{array}{c}\text { Internet } \\
\text { Road signs }\end{array}$}} & $15.3 \%$ & & \multirow{2}{*}{\multicolumn{2}{|c|}{$\begin{array}{l}\text { How many } \\
\text { times }\end{array}$}} & \multirow{2}{*}{$21.7 \%$} \\
\hline & & & $8.1 \%$ & & & & \\
\hline \multirow{4}{*}{$\begin{array}{l}\text { Length of } \\
\text { stay }\end{array}$} & \multirow{2}{*}{\multicolumn{2}{|c|}{$\begin{array}{c}\text { No overnight stay } \\
\text { A full day }\end{array}$}} & $14.4 \%$ & \multirow{4}{*}{ Transportation } & \multicolumn{2}{|c|}{ Personal car } & $52.8 \%$ \\
\hline & & & $11.7 \%$ & & \multirow{2}{*}{\multicolumn{2}{|c|}{$\begin{array}{c}\text { Bus } \\
\text { Airplane }\end{array}$}} & $31.1 \%$ \\
\hline & \multicolumn{2}{|c|}{ 2-3 night and day } & $28.3 \%$ & & & & $10.3 \%$ \\
\hline & \multicolumn{2}{|c|}{ More than 3 nights } & $45.6 \%$ & & \multicolumn{2}{|c|}{$\begin{array}{l}\text { Another } \\
\text { shape }\end{array}$} & $5.8 \%$ \\
\hline \multirow[t]{2}{*}{ Residence } & $\begin{array}{l}\text { Hotel and } \\
\text { hospitality }\end{array}$ & $\begin{array}{l}\text { Home } \\
\text { relatives } \\
\text { and } \\
\text { friends } \\
\end{array}$ & Camp & $\begin{array}{l}\text { Camping on the } \\
\text { street }\end{array}$ & Schools & $\begin{array}{l}\text { Leased } \\
\text { houses }\end{array}$ & $\begin{array}{c}\text { Hospitality } \\
\text { Office }\end{array}$ \\
\hline & $32.8 \%$ & $30.8 \%$ & $4.4 \%$ & $8.6 \%$ & $4.2 \%$ & $9.2 \%$ & $10 \%$ \\
\hline
\end{tabular}

The sources of information about Ardabil based on the results (Table 2) include TV, national and local newspapers, information received from friends, relatives, websites, networks, signs and road signposts. The polls show that sources were $27.2 \%$ (98) TV, $14.7 \%$ (53) newspapers, 34.7\% (125) through information received from friends and acquaintances, $15.3 \%$ (55) on the Internet and $8.1 \%$ (29) through the road signs from this destination. 33.3 percent (162) of people surveyed in Ardabil were there for the first time, while $45 \%$ (120) were there for the second time, and $21.7 \%$ (78) for the third or more. According to the length of stay, respondents can be grouped into four levels:

(a) Those who did not have a night stay in the city of Ardabil; 
(b) Those who stayed in Ardabil for one night;

(c) Those who stayed in Ardabil 2-3 nights; and

(d)Those who stayed in Ardabil for more than 3 nights. Frequently, the fourth group has the largest share among respondents.

$52.8 \%$ (190) of the tourists used their personal cars to travel to Ardabil city. $31.1 \%$ (112) used buses, $10.3 \%$ (37) used airplanes, and 5.8\% (21) used other forms of transport.

In terms of residence, $32.8 \%$ (118) stayed in hotels and hospitality; 30.8 (111) stayed with relatives and friends; $4.4 \%$ (16) in the park and camp; $8.6 \%$ (31) camped on the street; $4.2 \%$ (15) stayed in schools; $9.2 \%$ (33) stayed in leased houses, and $10 \%$ (36) resided in the Hospitality Office.

\section{Testing the Hypotheses}

Tourists experienced different levels of satisfaction based on demographic characteristics (age, gender, marital status, education, employment) from the tourism product of Ardabil city.

When assessing the effect of demographic variables (gender, marital status, age, occupation, level of education) on satisfaction with cultural attractions, the results of the test showed two significant values for the gifts of 0.036 , which is less than $0.05 \mathrm{~mm}(\mathrm{P}-$ Value $=\mathrm{sig}<0 / 05)$. Therefore, the souvenir factor for the age group under 20 years of age has a significant effect on cultural satisfaction with 95\% confidence in the satisfaction of tourists. The factor of local cuisine with a value of 0.005 for the working class and the factor of the variety of activities with a value of 0.023 for men have also been impressive in satisfying cultural attractions.

The results of marital status and education emphasize the independence between the variables of cultural attractions and satisfaction. As can be seen in Table 3, the meaningful value for all indicators of cultural attractions related to marriage and education is greater than the significance level 0.05 . Therefore, the status of education and marital status of tourists did not affect the satisfaction of cultural attractions $(\mathrm{P}$-value $=\mathrm{sig}>0 / 05)$.

Therefore, among demographic characteristics age, employment and gender are significant. Therefore the hypotheses derived from the main hypothesis are admitted.

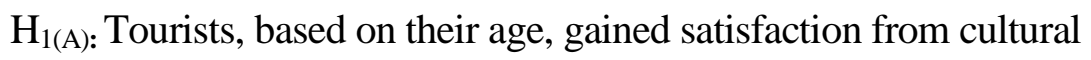
attractions.

$\mathrm{H}_{1(\mathrm{~B}):}$ Tourists based on employment received different levels of satisfaction from cultural attractions.

$\mathrm{H}_{1(\mathrm{C}):}$ Tourists based on gender received different levels of satisfaction from cultural attractions. 
According to the statistics presented in Table 4 about the natural and historical attractions in the study site, the results of the $\mathrm{X}^{2}$ test indicate that the status of the gardens and green spaces for respondents aged of 30-39 and 40-44 are respectively 0.042 and 0.023 . The factor of historical sites and ancient monuments has a value of 0.049 for those over 60 , and the urban suburban factor has a value of 0.031 for people 39-30. These factors have thus been effective in creating the satisfaction of tourists.

In addition, the results of the $\mathrm{X}^{2}$ test for different educational periods indicate that the Satisfaction of green areas with the amount (0.026), historical sites with the value (0.046) and suburban with the value (0.032). For the Level of Education, the vegetation cover and animal and special events with the amount of $(0.003)$ for the Master's and PhD's, have been effective in satisfying historical and cultural attractions. Among the various jobs, the worker's group was satisfied with the amount of vegetation and animals (0.035), certain natural events, landscapes (0.046), and the status of gardens and green spaces (0.018). The Employee Corps (0.006) was satisfied with the status of the booths and the green area. Individuals with free jobs (0.042) were satisfied with the climate of the city, while students (0.022) were satisfied with the green spaces and parks. Married people were also satisfied with the amount of (0.004) the status of the park and green space.

Therefore, in this hypothesis, all five demographic characteristics are meaningful. The hypotheses derived from the main hypothesis are as follows:

$\mathrm{H}_{1(\mathrm{D}) \text { : }}$ Tourists based on age have obtained different levels of satisfaction from natural and historical attractions.

$\mathrm{H}_{1(\mathrm{E}):}$ Tourists based on education received different levels of satisfaction from natural and historical attractions.

$\mathrm{H}_{1(\mathrm{~F}) \text { : }}$ Tourists based on employment received different levels of satisfaction from natural and historical attractions.

$\mathrm{H}_{1(\mathrm{G}) \text { : }}$ Tourists based on gender received different levels of satisfaction from natural and historical attractions.

$\mathrm{H}_{1(\mathrm{H}) \text { : }}$ Tourists based on age have obtained different levels of satisfaction from natural and historical attractions. 
Table 3. Measuring the Impact of Demographic Variables on Satisfaction with Cultural Attractions

\begin{tabular}{|c|c|c|c|c|c|c|c|c|c|c|c|c|c|c|c|c|}
\hline \multirow[t]{2}{*}{ Variables } & \multicolumn{2}{|c|}{$\begin{array}{l}\text { Services and cultural } \\
\text { facilities }\end{array}$} & \multicolumn{2}{|c|}{$\begin{array}{c}\text { Entertainment } \\
\text { services and } \\
\text { facilities }\end{array}$} & \multicolumn{2}{|c|}{$\begin{array}{l}\text { Variety of } \\
\text { activities }\end{array}$} & \multicolumn{2}{|c|}{$\begin{array}{l}\text { Traditions and } \\
\text { local customs }\end{array}$} & \multicolumn{2}{|c|}{ Souvenir } & \multicolumn{2}{|c|}{ Art and Craft } & \multicolumn{2}{|c|}{ Local food } & \multicolumn{2}{|c|}{$\begin{array}{c}\text { Friendly } \\
\text { behavior and } \\
\text { hospitality of } \\
\text { the host } \\
\text { community }\end{array}$} \\
\hline & Sig. & $\mathrm{X}^{2}$ & Sig. & $X^{2}$ & Sig. & $X^{2}$ & Sig. & $\mathrm{X}^{2}$ & Sig. & $\mathrm{X}^{2}$ & Sig. & $\mathrm{X}^{2}$ & Sig. & $\mathrm{X}^{2}$ & Sig. & $X^{2}$ \\
\hline $20>$ & 0.945 & 1.198 & 0.819 & 2.216 & 0.565 & 3.893 & 0.504 & 4.320 & 0.036 & 11.932 & 0.491 & 4.419 & 0.690 & 3.062 & 0.362 & 5.460 \\
\hline 20-29 & 0.317 & 5.893 & 0.339 & 5.672 & 0.108 & 9.034 & 0.408 & 5.061 & 0.986 & 0.633 & 0.098 & 9.292 & 1.000 & 0.139 & 0.673 & 3.172 \\
\hline 30-39 & 0.572 & 3.841 & 0.291 & 6.163 & 0.102 & 9.170 & 0.145 & 8.207 & 0.745 & 2.705 & 0.274 & 6.347 & 0.737 & 2.761 & 0.318 & 5.884 \\
\hline 40-49 & 0.497 & 4.370 & 0.597 & 3.677 & 0.232 & 6.853 & 0.574 & 3.834 & 0.842 & 2.055 & 0.512 & 4.264 & 0.416 & 5.002 & 0.382 & 5.283 \\
\hline 50-59 & 0.960 & 1.035 & 0.110 & 9.876 & 0.551 & 3.990 & 0.809 & 2.283 & 0.381 & 5.295 & 0.248 & 6.647 & 0.475 & 3.519 & 0.417 & 3.921 \\
\hline $60 \leq$ & 0.759 & 1.875 & 0.555 & 3.958 & 0.526 & 4.167 & 0.349 & 5.580 & 0.645 & 2.500 & 0.708 & 2.946 & 0.237 & 6.786 & 0.870 & 1.250 \\
\hline Education & Sig. & $X^{2}$ & Sig. & $X^{2}$ & Sig. & $\mathrm{X}^{2}$ & Sig. & $\mathrm{X}^{2}$ & Sig. & $\mathrm{X}^{2}$ & Sig. & $\mathrm{X}^{2}$ & Sig. & $\mathrm{X}^{2}$ & Sig. & $\mathrm{X}^{2}$ \\
\hline $\begin{array}{l}\text { Primary school } \\
\text { only }\end{array}$ & 0.575 & 3.824 & 0.845 & 2.028 & 0.374 & 5.355 & 0.947 & 1.180 & 0.353 & 5.547 & 0.520 & 4.205 & 0.353 & 5.545 & 0.249 & 6.634 \\
\hline $\begin{array}{l}\text { High School } \\
\text { degree }\end{array}$ & 0.654 & 3.299 & 0.138 & 8.346 & 0.426 & 4.920 & 0.803 & 2.319 & 0.478 & 4.515 & 0.465 & 4.614 & 0.416 & 5.000 & 0.934 & 1.308 \\
\hline $\begin{array}{c}\text { University } \\
\text { Courses }\end{array}$ & 0.233 & 6.839 & 0.529 & 4.140 & 0.895 & 1.649 & 0.936 & 1.291 & 0.721 & 2.866 & 0.587 & 2.829 & 0.604 & 3.628 & 0.625 & 3.490 \\
\hline $\begin{array}{c}\text { University } \\
\text { degree }\end{array}$ & 0.171 & 7.744 & 0.850 & 1.996 & 0.470 & 4.577 & 0.249 & 6.632 & 0.654 & 3.298 & 0.663 & 3.240 & 0.597 & 3.677 & 0.604 & 3.627 \\
\hline $\begin{array}{l}\text { Master's and } \\
\text { Ph.D. }\end{array}$ & 0.478 & 4.517 & 0.827 & 2.158 & 0.035 & 11.968 & 0.373 & 0.5363 & 0.222 & 6.980 & 0.179 & 7.619 & 0.699 & 3.006 & 0.966 & 0.955 \\
\hline Employment & Sig. & $X^{2}$ & Sig. & $X^{2}$ & Sig. & $\mathrm{X}^{2}$ & Sig. & $X^{2}$ & Sig. & $X^{2}$ & Sig. & $\mathrm{X}^{2}$ & Sig. & $\mathrm{X}^{2}$ & Sig. & $X^{2}$ \\
\hline Specialists & 0.633 & 3.434 & 0.447 & 2.492 & 0.720 & 2.088 & 0.178 & 4.916 & 0.528 & 2.222 & 0.135 & 7.022 & 0.166 & 6.483 & 0.330 & 4.611 \\
\hline Employees & 0.559 & 3.932 & 0.691 & 3.060 & 0.232 & 6.850 & 0.596 & 3.685 & 0.690 & 3.067 & 0.136 & 8.383 & 0.880 & 1.773 & 0.548 & 4.010 \\
\hline $\begin{array}{c}\text { Free } \\
\text { occupation }\end{array}$ & 0.913 & 1.502 & 0.054 & 10.85 & 0.358 & 5.497 & 0.303 & 6.035 & 0.877 & 1.796 & 0.960 & 1.036 & 0.542 & 4.051 & 0.935 & 1.299 \\
\hline Workers & 0.446 & 2.667 & 0.292 & 3.733 & 0.018 & 8.000 & 0.406 & 4.000 & 0.349 & 4.444 & 0.777 & 1.778 & 0.005 & 8.000 & 0.587 & 1.067 \\
\hline Unemployed & 0.865 & 1.881 & 0.131 & 8.488 & 0.622 & 3.507 & 0.242 & 6.730 & 0.479 & 4.506 & 0.148 & 8.150 & 0.676 & 3.154 & 0.261 & 6.489 \\
\hline Students & 0.724 & 2.842 & 0.361 & 5.469 & 0.105 & 9.095 & 0.138 & 8.253 & 0.175 & 7.676 & 0.287 & 6.197 & 0.684 & 3.101 & 0.592 & 3.707 \\
\hline Gender & Sig. & $\mathrm{X}^{2}$ & Sig. & $X^{2}$ & Sig. & $X^{2}$ & Sig. & $X^{2}$ & Sig. & $\mathrm{X}^{2}$ & Sig. & $\mathrm{X}^{2}$ & Sig. & $\mathrm{X}^{2}$ & Sig. & $\mathrm{X}^{2}$ \\
\hline Men & 0.082 & 9.764 & 0.684 & 3.102 & 0.057 & 10.737 & 0.514 & 4.252 & 0.756 & 2.578 & 0.637 & 3.407 & 0.913 & 1.500 & 0.780 & 2.480 \\
\hline Women & 0.867 & 1.871 & 0.880 & 1.769 & 0.023 & 12.999 & 0.442 & 4.793 & 0.167 & 7.813 & 0.730 & 2.805 & 0.645 & 3.359 & 0.760 & 2.612 \\
\hline Marital status & Sig. & $\mathrm{X}^{2}$ & Sig. & $\mathrm{X}^{2}$ & Sig. & $\mathrm{X}^{2}$ & Sig. & $\mathrm{X}^{2}$ & Sig. & $\mathrm{X}^{2}$ & Sig. & $\mathrm{X}^{2}$ & Sig. & $\mathrm{X}^{2}$ & Sig. & $\mathrm{X}^{2}$ \\
\hline Single & 0.315 & 5.914 & 0.060 & 10.596 & 0.089 & 9.537 & 0.293 & 6.144 & 0.239 & 6.760 & 0.674 & 3.167 & 0.652 & 3.315 & 0.373 & 5.362 \\
\hline Married & 0.994 & 0.459 & 0.627 & 3.477 & 0.319 & 5.869 & 0.055 & 10.831 & 0.743 & 2.719 & 0.735 & 2.773 & 0.977 & 0.794 & 0.609 & 0.3598 \\
\hline
\end{tabular}


Table 4. Measuring the Impact of Demographic Variables on Satisfaction with Historical and Natural Attractions

\begin{tabular}{|c|c|c|c|c|c|c|c|c|c|c|c|c|c|c|c|c|}
\hline \multirow{2}{*}{$\begin{array}{c}\text { Variables } \\
\text { Age }\end{array}$} & \multicolumn{2}{|c|}{$\begin{array}{l}\text { Vegetation and } \\
\text { animal and } \\
\text { special events }\end{array}$} & \multicolumn{2}{|c|}{$\begin{array}{l}\text { Mineral hot } \\
\text { water }\end{array}$} & \multicolumn{2}{|c|}{$\begin{array}{l}\text { Landscapes and } \\
\text { natural scenery }\end{array}$} & \multicolumn{2}{|c|}{ Architecture } & \multicolumn{2}{|c|}{$\begin{array}{l}\text { The status of } \\
\text { parks and green } \\
\text { space }\end{array}$} & \multicolumn{2}{|c|}{$\begin{array}{c}\text { Historical sites } \\
\text { and ancient } \\
\text { monument }\end{array}$} & \multicolumn{2}{|c|}{$\begin{array}{l}\text { Metropolitan } \\
\quad \text { area }\end{array}$} & \multicolumn{2}{|c|}{$\begin{array}{l}\text { Enjoyable } \\
\text { weather }\end{array}$} \\
\hline & Sig. & $\mathrm{X}^{2}$ & Sig. & $\mathrm{X}^{2}$ & Sig. & $X^{2}$ & Sig. & $\mathrm{X}^{2}$ & Sig. & $\mathrm{X}^{2}$ & Sig. & $\mathrm{X}^{2}$ & Sig. & $\mathrm{X}^{2}$ & Sig. & $\mathrm{X}^{2}$ \\
\hline $20>$ & 0.528 & 3.178 & 0.707 & 2.155 & 0.891 & 1.681 & 0.453 & 4.702 & 0.849 & 1.998 & 0.633 & 3.436 & 0.538 & 3.769 & 0.866 & 1.876 \\
\hline $20-29$ & 262 & 6.478 & 498 & 4.363 & 764 & 2.584 & 162 & 7.890 & .363 & 5.452 & .534 & 4.106 & 0.219 & 7.021 & .565 & 3.891 \\
\hline $30-39$ & 59 & 7.952 & 753 & 2.654 & .075 & 10.014 & .705 & 2.966 & .042 & 11.496 & 0.204 & 7.235 & 0.031 & 12.301 & 132 & 8.475 \\
\hline $40-49$ & 923 & 1.416 & 0.558 & 3.939 & 0.748 & 2.687 & 0.137 & 8.369 & 0.023 & 12.993 & 0.483 & 4.475 & 0.056 & 10.769 & 0.342 & 5.652 \\
\hline $50-59$ & 601 & 3.646 & 0.421 & 4.962 & 0.343 & 5.639 & 0.765 & 2.573 & 0.892 & 1.672 & 0.782 & 2.461 & 0.892 & 1.673 & 0.581 & 3.784 \\
\hline $60 \leq$ & 0.745 & 2.708 & 0.741 & 1.970 & 0.753 & 2.665 & 0.573 & 3.838 & 0.633 & 3.438 & 0.049 & 9.523 & 0.837 & 2.083 & 0.163 & 7.877 \\
\hline Education & Sig. & $\mathrm{X}^{2}$ & Sig. & $\mathrm{X}^{2}$ & Sig. & $\mathrm{X}^{2}$ & Sig. & $\mathrm{X}^{2}$ & Sig. & $\mathrm{X}^{2}$ & Sig. & $\mathrm{X}^{2}$ & Sig. & $\mathrm{X}^{2}$ & Sig. & $\mathrm{X}^{2}$ \\
\hline $\begin{array}{c}\text { Primary } \\
\text { school only }\end{array}$ & 0.834 & 2.109 & 0.793 & 2.392 & 0.227 & 6.909 & 0.724 & 2.8 & 0.561 & 3.920 & 0.535 & 4.102 & 0.683 & 3.110 & 0.648 & 3.107 \\
\hline $\begin{array}{l}\text { High School } \\
\text { degree }\end{array}$ & 0.818 & 2.222 & 0.476 & 4.531 & 0.504 & 4.320 & 0.213 & 7.106 & 0.492 & 4.413 & 0.610 & 3.588 & 0.540 & 4.064 & 0.143 & 8.244 \\
\hline $\begin{array}{c}\text { University } \\
\text { Courses }\end{array}$ & 0.728 & 2.816 & 0.604 & 2.732 & 0.390 & 5.213 & 0.396 & 5.167 & 0.316 & 4.727 & 0.672 & 3.185 & 0.402 & 5.117 & 0.325 & 4.649 \\
\hline $\begin{array}{c}\text { University } \\
\text { degree }\end{array}$ & 0.587 & 3.741 & 0.245 & 6.682 & 0.297 & 6.098 & 0.852 & 1 & 0.026 & 12.712 & 0.046 & 11.305 & 0.032 & 12.219 & 0.710 & 2.935 \\
\hline $\begin{array}{l}\text { Master's and } \\
\text { Ph.D. }\end{array}$ & 0.003 & 17.977 & 0.896 & 1.645 & 0.168 & 7.855 & 0.657 & 3.277 & 0.749 & 2.683 & 0.160 & 7.926 & 0.112 & 8.937 & 0.520 & 4.209 \\
\hline Employment & Sig. & $\mathrm{X}^{2}$ & Sig. & $\mathrm{X}^{2}$ & Sig. & $X^{2}$ & Sig. & $\mathrm{X}^{2}$ & Sig. & $\mathrm{X}^{2}$ & Sig. & $\mathrm{X}^{2}$ & Sig. & $\mathrm{X}^{2}$ & Sig. & $\mathrm{X}^{2}$ \\
\hline Specialists & 416 & 5.002 & 962 & 1.010 & 830 & 1.481 & .444 & 3.728 & 0.583 & 2.854 & 0.410 & 5.051 & 0.056 & 9.226 & 0.798 & 2.357 \\
\hline Employees & 0.343 & 5.637 & 0.090 & 9.528 & 0.741 & 2.731 & 0.069 & 10.216 & 0.006 & 16.232 & 0.441 & 4.800 & 0.916 & 1.479 & 0.314 & 5.923 \\
\hline $\begin{array}{c}\text { Free } \\
\text { occupation }\end{array}$ & 0.067 & 10.292 & 0.908 & 1.547 & 0.879 & 1.781 & 0.638 & 3.405 & 0.414 & 5.012 & 0.433 & 4.859 & 0.069 & 10.244 & 0.042 & 11.517 \\
\hline Workers & 0.035 & 4.444 & 0.292 & 3.733 & 0.046 & 8.000 & 0.135 & 4.000 & 0.018 & $\overline{00}$ & 0.2 & 4.444 & 0.149 & 5.3 & 0.169 & 3.556 \\
\hline Unemployed & 41 & 6.732 & 0.279 & 6.289 & 0.064 & 10.433 & 447 & 4.748 & 66 & 7.833 & 0.620 & 3.525 & 0.501 & 4.342 & 0.397 & 5.155 \\
\hline Students & 0.070 & 10.191 & 0.543 & 4.047 & 0.615 & 3.556 & 0.022 & 13.130 & 0.538 & 4.082 & 0.767 & 2.560 & 0.994 & 0.439 & 0.693 & 3.048 \\
\hline Gender & Sig. & $\mathrm{X}^{2}$ & Sig. & $\mathrm{X}^{2}$ & Sig. & $\mathrm{X}^{2}$ & Sig. & $\mathrm{X}^{2}$ & Sig. & $\mathrm{X}^{2}$ & Sig. & $\mathrm{X}^{2}$ & Sig. & $\mathrm{X}^{2}$ & Sig. & $\mathrm{X}^{2}$ \\
\hline Men & 320 & 5.865 & .05 & 10.929 & 0.137 & 8.373 & 0.451 & 4.723 & 0.114 & 8.872 & 0.884 & 1.739 & 0.748 & 2.689 & 0.640 & 3.393 \\
\hline Women & 0.358 & 5.504 & 0.332 & 5.746 & 0.554 & 3.967 & 0.245 & 6.691 & 0.002 & 18.468 & 0.202 & 7.261 & 0.147 & 8.173 & 0.269 & 6.407 \\
\hline Marital status & Sig. & $X^{2}$ & Sig. & $\mathrm{X}^{2}$ & Sig. & $X^{2}$ & Sig. & $\mathrm{X}^{2}$ & Sig. & $X^{2}$ & Sig. & $X^{2}$ & Sig. & $\mathrm{X}^{2}$ & Sig. & $\mathrm{X}^{2}$ \\
\hline Single & 0.062 & 10.528 & 0.749 & 2.682 & 0.753 & 2.652 & 0.595 & 3.687 & 0.290 & 6.175 & 0.882 & 1.751 & 0.730 & 2.808 & 0.873 & 1.823 \\
\hline Married & 0.643 & 3.370 & 0.970 & 0.909 & 0.217 & 7.053 & 0.383 & 5.274 & 0.004 & 17.143 & 0.388 & 5.230 & 0.078 & 9.911 & 0.225 & 6.943 \\
\hline
\end{tabular}


Table 5. Measuring the Impact of Demographic Variables on the Satisfaction of Infrastructure

\begin{tabular}{|c|c|c|c|c|c|c|c|c|c|c|c|c|c|c|c|c|}
\hline \multirow{2}{*}{$\begin{array}{c}\text { Variables } \\
\sum_{0}^{\infty 0} 0\end{array}$} & \multicolumn{2}{|c|}{$\begin{array}{c}\text { Accommodation } \\
\text { facility }\end{array}$} & \multicolumn{2}{|c|}{$\begin{array}{l}\text { Restaurant and } \\
\text { food preparation }\end{array}$} & \multicolumn{2}{|c|}{ Traffic and bustle } & \multicolumn{2}{|c|}{$\begin{array}{c}\text { Tourism } \\
\text { information } \\
\text { centers }\end{array}$} & \multicolumn{2}{|c|}{$\begin{array}{l}\text { Destination } \\
\text { cleanliness }\end{array}$} & \multicolumn{2}{|c|}{ Security } & \multicolumn{2}{|c|}{ Toilets } & \multicolumn{2}{|c|}{$\begin{array}{c}\text { Signs (signs, } \\
\text { guides, tags, } \\
\text { brochures, etc.) }\end{array}$} \\
\hline & Sig. & $\mathrm{X}^{2}$ & Sig. & $\mathrm{X}^{2}$ & Sig. & $\mathrm{X}^{2}$ & Sig. & $\mathrm{X}^{2}$ & Sig. & $\mathrm{X}^{2}$ & Sig. & $\mathrm{X}^{2}$ & Sig. & $\mathrm{X}^{2}$ & Sig. & $\mathrm{X}^{2}$ \\
\hline $20>$ & 0.611 & 3.579 & 0.084 & 9.721 & 0.562 & 3.912 & 0.271 & 6.375 & 0.935 & 1.301 & 0.520 & 4.209 & 0.249 & 6.638 & 0.747 & 2.696 \\
\hline $20-29$ & 0.563 & 3.904 & 0.906 & 1.558 & 0.948 & 1.168 & 0.221 & 6.989 & 0.319 & 5.867 & 0.227 & 6.920 & 0.695 & 3.034 & 0.462 & 4.632 \\
\hline $30-39$ & 0.279 & 6.287 & 0.472 & 4.557 & 0.485 & 4.465 & 0.182 & 7.569 & 0.145 & 8.215 & 0.936 & 1.286 & 0.075 & 10.008 & 0.024 & 12.892 \\
\hline $40-49$ & 0.999 & 0.243 & 0.955 & 1.090 & 0.619 & 3.530 & 0.420 & 4.964 & 0.153 & 8.061 & 0.868 & 1.861 & 0.199 & 7.307 & 0.621 & 3.517 \\
\hline $50-59$ & 0.551 & 3.990 & 0.401 & 5.124 & 0.297 & 4.910 & 0.266 & 6.432 & 0.809 & 2.282 & 0.161 & 7.906 & 0.280 & 6.277 & 0.082 & 9.761 \\
\hline $60 \leq$ & 0.379 & 5.313 & 0.622 & 3.512 & 0.196 & 6.042 & 0.845 & 2.028 & 0.416 & 5.000 & 0.586 & 3.750 & 0.469 & 2.536 & 0.258 & 6.526 \\
\hline education & Sig. & $\mathrm{X}^{2}$ & Sig. & $\mathrm{X}^{2}$ & Sig. & $\mathrm{X}^{2}$ & Sig. & $\mathrm{X}^{2}$ & Sig. & $\mathrm{X}^{2}$ & Sig. & $\mathrm{X}^{2}$ & Sig. & $X^{2}$ & Sig. & $\mathrm{X}^{2}$ \\
\hline $\begin{array}{c}\text { Primary school } \\
\text { only }\end{array}$ & 0.005 & 16.778 & 0.091 & 9.503 & 0.461 & 4.643 & 0.329 & 5.776 & 0.307 & 5.994 & 0.258 & 6.535 & 0.250 & 6.621 & 0.279 & 6.287 \\
\hline $\begin{array}{l}\text { High School } \\
\text { degree }\end{array}$ & 0.505 & 4.317 & 0.469 & 4.580 & 0.915 & 1.484 & 0.807 & 2.292 & 0.070 & 10.205 & 0.915 & 1.482 & 0.193 & 7.401 & 0.327 & 5.792 \\
\hline $\begin{array}{c}\text { University } \\
\text { Courses }\end{array}$ & 0.244 & 66.99 & 0.497 & 4.375 & 0.975 & 0.826 & 0.445 & 4.765 & 0.183 & 7.543 & 0.728 & 2.820 & 0.570 & 3.855 & 0.736 & 2.766 \\
\hline $\begin{array}{c}\text { University } \\
\text { degree }\end{array}$ & 0.586 & 3.751 & 0.416 & 4.996 & 0.024 & 12.906 & 0.062 & 10.505 & 0.726 & 2.843 & 0.519 & 4.212 & 0.188 & 7.472 & 0.327 & 5.789 \\
\hline $\begin{array}{l}\text { Master's and } \\
\text { Ph.D. }\end{array}$ & 0.573 & 3.837 & 0.152 & 8.077 & 0.314 & 5.920 & 0.462 & 4.633 & 0.133 & 8.451 & 0.673 & 3.177 & 0.471 & 4.565 & 0.573 & 0.3835 \\
\hline Employment & Sig. & $\mathrm{X}^{2}$ & Sig. & $\mathrm{X}^{2}$ & Sig. & $\mathrm{X}^{2}$ & Sig. & $\mathrm{X}^{2}$ & Sig. & $\mathrm{X}^{2}$ & Sig. & $\mathrm{X}^{2}$ & Sig. & $X^{2}$ & Sig. & $X^{2}$ \\
\hline Specialists & 0.425 & 4.926 & 0.509 & 3.300 & 0.646 & 2.492 & 0.707 & 2.155 & 0.296 & 4.916 & 0.709 & 2.941 & 0.245 & 6.685 & 0220 & 7.013 \\
\hline Employees & 0.834 & 1.458 & 0.068 & 10.283 & 0.492 & 4.410 & 0.195 & 7.360 & 0.831 & 2.129 & 0.183 & 7.548 & 0.793 & 2.390 & 0.672 & 3.181 \\
\hline Free occupation & 0.862 & 1.907 & 0.444 & 4.776 & 0.032 & 12.220 & 0.206 & 7.200 & 0.948 & 1.164 & 0.843 & 2.045 & 0.243 & 6.715 & 0.667 & 3.215 \\
\hline Workers & 0.261 & 4.000 & 0.217 & 4.444 & 0.046 & 8.000 & 0.018 & 8.000 & 0.149 & 5.333 & 0.155 & 3.733 & 0.217 & 0.444 & 0.046 & 8.000 \\
\hline Unemployed & 0.832 & 2.121 & 0.001 & 22.004 & 0.077 & 9.949 & 0.535 & 4.100 & 0.214 & 7.090 & 0.287 & 6.201 & 0.502 & 4.340 & 0.758 & 2.619 \\
\hline Students & 0.779 & 2.486 & 0.438 & 4.820 & 0.246 & 6.680 & 0.076 & 9.966 & 0.574 & 3.833 & 0.687 & 3.087 & 0.572 & 3.845 & 0.728 & 2.819 \\
\hline Gender & Sig. & $X^{2}$ & Sig. & $X^{2}$ & Sig. & $X^{2}$ & Sig. & $\mathrm{X}^{2}$ & Sig. & $X^{2}$ & Sig. & $\mathrm{X}^{2}$ & Sig. & $X^{2}$ & Sig. & $\mathrm{X}^{2}$ \\
\hline Men & 0.114 & 8.890 & 0.068 & 10.264 & 0.927 & 1.371 & 0.049 & 11.099 & 0.085 & 9.666 & 0.028 & 12.587 & 0.601 & 3.652 & 0.603 & 3.635 \\
\hline Women & 0.297 & 6.095 & 0.271 & 6.385 & 0.897 & 1.631 & 0.913 & 1.497 & 0.562 & 3.913 & 0.796 & 2.372 & 0.218 & 7.039 & 0.208 & 7.178 \\
\hline Marital status & Sig. & $\mathrm{X}^{2}$ & Sig. & $\mathrm{X}^{2}$ & Sig. & $\mathrm{X}^{2}$ & Sig. & $\mathrm{X}^{2}$ & Sig. & $\mathrm{X}^{2}$ & Sig. & $\mathrm{X}^{2}$ & Sig. & $\mathrm{X}^{2}$ & Sig. & $\mathrm{X}^{2}$ \\
\hline Single & 0.104 & 9.137 & 0.634 & 3.430 & 0.930 & 1.349 & 0.011 & 14.946 & 0.927 & 1.373 & 0.449 & 4.735 & 0.237 & 6.790 & 0.630 & 3.457 \\
\hline Married & 0.241 & 6.731 & 0.863 & 1.896 & 0.886 & 1.725 & 0.730 & 2.803 & 0.223 & 6.962 & 0.708 & 2.950 & 0.643 & 3.373 & 0.654 & 3.301 \\
\hline
\end{tabular}


According to the statistics and information available in Table 5 on natural and historical attractions, the $\mathrm{X}^{2}$ test results indicate that the age group of 30 to 39 years of age agreed with the signs of guidance (0.024). Tourists with elementary education only with the amount (0.05) of the residence and and tourists with university education is satisfied with the amount (0.024) of traffic. The Workers' Corps agreed on traffic and traffic congestion with a value of 0.046 , tourism information centers with a value of 0.018 and indications with a value of 0.046 . Individuals with free jobs (0.032) were delighted with traffic and traffic conditions. Unemployed persons (0.001) agreed on the status of the restaurant and the provision of food, while women agreed on the informational agents of tourism and security with the values (0.049) and (0.028). Finally, single people were satisfied with the amount (0.011) of tourism information centers.

Therefore, in this hypothesis, all five demographic characteristics are meaningful. The hypotheses derived from the main hypothesis are:

$\mathrm{H}_{1(\mathrm{I})}$ : Tourists, based on age, obtained satisfaction from infrastructures.

$\mathrm{H}_{1(\mathrm{~J})}$ : Tourists on the basis of education received different levels of satisfaction from the infrastructure.

$\mathrm{H}_{1(\mathrm{~K})}$ : Tourists based on employment received different levels of satisfaction from the infrastructure.

$\mathrm{H}_{1(\mathrm{~L})}$ : Tourists based on gender received different levels of satisfaction by infrastructure.

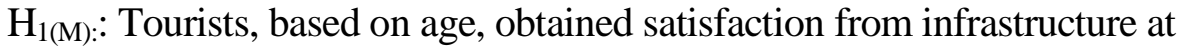
different levels.

According to the statistics and data presented in Table 6, comparing the differences in the means of gender variables, marital status, age, occupation and education indicates that the gender variable of men is 1.2965 and of women 1.2484; in the variables for marital status, married people with an average of 1.3019 and single with an average of 1.2365 with a $99 \%$ confidence in this regard have a significant effect. The highest averages of each variable are for men and married.

Comparison of the differences in averages of different age groups suggests that the age range of 50-59 years with the highest averages of age was 1.4483 with $95 \%$ confidence in future behavioral tendencies of tourists. Other age groups are 40- 49 years old with an average of 1.3721, 39-30 years with an average of 1.3119, over 60 with an average of $1.3000<20$ with an average of 1.2333 and 20-29 years with an average of 1.1461 with a confidence of $99 \%$.

The comparison of the differences between the various jobs shows that the specialists group with the first average of 1.5 and the next level of the Worker's Corner with an average of 1.375 with $95 \%$ confidence in the relationship between satisfaction and future behavioral tendencies of tourists have a significant effect. At the next level, free occupations with an average of 1.3095, employees with an average of 1.3, unemployed 1.2338, and student with an average of 1.2079 with a $99 \%$ confidence, show a significant effect. 
Among the various educational courses, the university courses with an average of 1.2857 with a $95 \%$ confidence have a significant effect (Table 7). The university degree with an average of 1.3094, high school degree with an average of 1.2909 , master's and $\mathrm{PhD}$ with a mean of 1.2698 , and primary school only with an average of 1.1912 with a $99 \%$ confidence in this regard. Therefore, it can be concluded that the significant age and occupation variables were 50-59 years and specialists and employees with high average. This result is given with $95 \%$ confidence in the future behavioral tendencies of tourists. However, in the course of studying, university courses were ranked third in terms of average value and recorded a significant effect with $95 \%$ confidence.

Table 6. Comparison of Demographic and Social Variables (gender, marital status, age, employment and education) Relative to Re-travel

\begin{tabular}{|c|c|c|c|c|c|c|c|}
\hline Gender & Average & Age & Average & Employment & Average & Education & Average \\
\hline Men & 1.2965 & $<20$ & 1.2333 & Specialists & 1.5000 & $\begin{array}{c}\text { Primary } \\
\text { school only }\end{array}$ & 1.1912 \\
\hline Women & 1.2484 & $20-29$ & 1.1461 & Employees & 1.3000 & $\begin{array}{c}\text { High School } \\
\text { degree }\end{array}$ & 1.2909 \\
\hline $\begin{array}{c}\text { Marital } \\
\text { status }\end{array}$ & Average & $30-39$ & 1.3119 & Free occupation & 1.3095 & $\begin{array}{c}\text { University } \\
\text { Courses }\end{array}$ & 1.2857 \\
\hline Single & 1.2365 & $40-49$ & 1.3721 & Workers & 1.3750 & $\begin{array}{c}\text { University } \\
\text { degree }\end{array}$ & 1.3094 \\
\hline \multirow{2}{*yyyyyyy}{ Married } & 1.3019 & $50-59$ & 1.4483 & Unemployed & 1.2338 & $\begin{array}{c}\text { Master's and } \\
\text { Ph.D. }\end{array}$ & 1.2698 \\
\cline { 2 - 7 } & $>60$ & 1.3000 & Students & 1.2079 & \multicolumn{2}{|c}{} \\
\hline
\end{tabular}

In order to study the satisfaction and behavioral tendencies of tourists' future, the distribution of two variables is shown in Figure 1. As seen in the corresponding figure, $70.6 \%$ of respondents chose yes for their overall satisfaction with this destination, and $29.4 \%$ chose the no-favor option. Regarding the decision to revisit the location, $72.5 \%$ of respondents registered the yes option, and $27.5 \%$ of the respondents chose the no option (Figure 1). Therefore, the results of these variables indicate that tourists have a high sense of loyalty to this destination.

Figure 1. Distribution of Satisfaction and Future Behavioral Tendencies
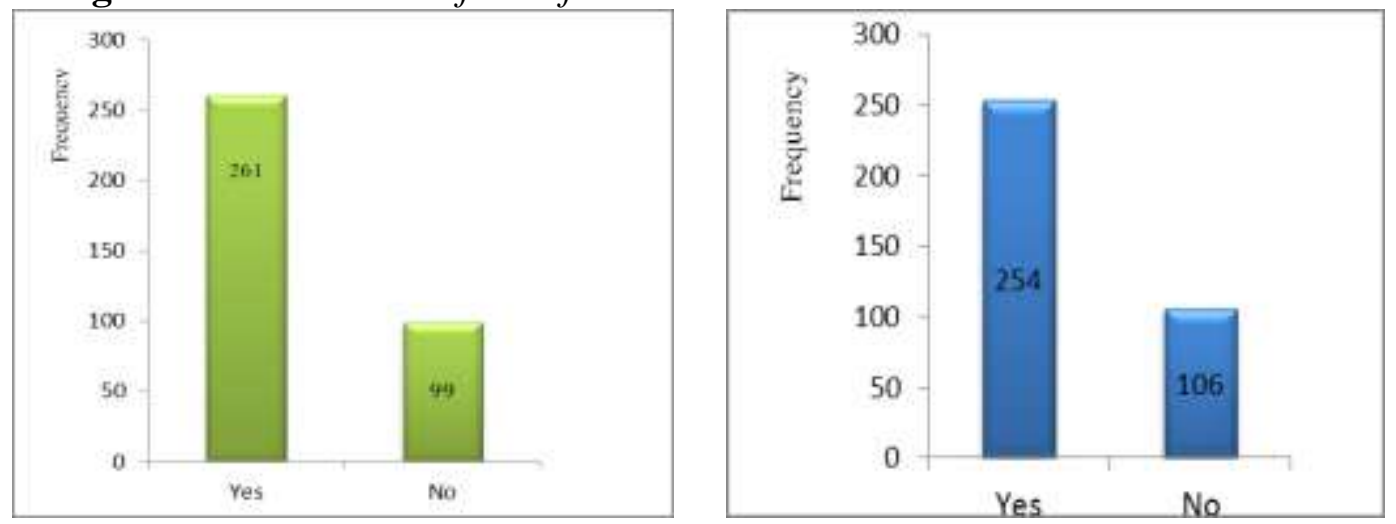
Table 7. Comparison of Satisfaction and Behavioral Desires of Future Tourists Based on Gender and Marital Status

\begin{tabular}{|c|c|c|c|c|c|c|c|c|c|c|c|}
\hline \multicolumn{4}{|c|}{ Marital status } & \multicolumn{4}{|c|}{ Satisfaction of tourists } & \multicolumn{4}{c|}{ Tend to come back } \\
\hline Frequency & Men & Frequency & Women & Frequency & Men & Frequency & Women & Frequency & Men & Frequency & Women \\
\hline 118 & & 94 & & 144 & Yes & 116 & Yes & 131 & Yes & 107 & Yes \\
& Married & & Married & & & & & & & & \\
\hline 81 & Single & 67 & Single & 55 & No & 45 & No & 68 & No & 54 & No \\
\hline
\end{tabular}


It should also be noted that according to the statistics presented in Table 7, among respondents, the satisfaction of men was higher than that of women and, consequently, they were more willing to travel again and had a higher sense of loyalty. Referring to Table 7 and reviewing the frequency, it can be stated that in regards to marital status, married people are more likely than single people to be satisfied, among whom, men are even more than women. In sum, a review of the frequency of extracted data from the questionnaires indicates that the overall satisfaction of men, as well as married people and families, has been more than the services and facilities of tourism in Ardabil.

\section{Conclusion}

The purpose of this study was to assess the satisfaction and loyalty of tourists from the tourism product of Ardabil city with an emphasis on demographic characteristics (gender, age, marital status, employment and education). In order to study the level of satisfaction, the tourism product of the city was divided into attractions (including cultural attractions, natural attractions and historical attractions) and facilities. According to the results, the cultural attractions indicators show that the age, occupation and gender variables were effective in satisfying the souvenir factor, local food and variety of activities. Investigating the indicators of natural and historical attractions and amenities showed that tourists, based on their age, marital status, employment, education, and gender, selected different levels of satisfaction from the tourism product. In addition, in order to evaluate the loyalty of tourists, the indicator of the decision to return to destination was evaluated, the results showed that there is a significant relationship between the variables of age, gender, marital status, education, employment, and loyalty of tourists. Collecting information related to tourist satisfaction is important for planning the destination in relation to dealing with travelers, the behavior of tourists and satisfaction with the quality of services and tourism products and it is important to have a regulatory planning.

The suggestions of this research include the creation of diverse tourism activities for women, the improvement of the status of greenhouses and gardens in the city, in order to improve the satisfaction of families, diversify the services of the police, such as being in the terminal and passenger terminals, airport, historical axes, police patrols in the natural areas of tourism, in order to increase the satisfaction of tourists, especially women, the use of catalogs and photographs of the tourist attractions of Ardabil, the use of public media and coverage of the attractions of the province and specialized magazines of tourism, the creation of information offices for tourists, set up an info tourism bank and other such measures. 


\section{References}

Aminbaydokhty A, Rohipour S (2013) The impact of demographic characteristics on customer expectations of quality of service in the hospitality industry of Semnan Province. Journal of Planning and Development of Tourism 6: 160-180.

Bardin L (1977) Analise de conteudo [Content analysis], Edicoes 70, Lisboa.

Cultural Heritage, Handicrafts and Tourism Organization of Ardabil Province (2016). http://ardabilchto.ir/0/FA/.

Ebrahimzadeh I, Vlashejordi Farahani R (2012) An analysis of the motives of tourists and the impact of gender and income on that case study; Nowruz Tourists in Mahallat City. Journal of Urban Studies 4: 1-10.

Eftekhari A, Pourtaheri M, Mahdavian F (2011) Prioritization of rural tourism in the city of Nair. Geography and Development 9(24): 23-38.

Forozia AR, Sadeghi Zadeh M, Hemmati Noedoust Gilani M (2013) Customer satisfaction in hospitality industry: Middle East tourists at 3star hotels in Malaysia. Research Journal of Applied Sciences, Engineering and Technology 5(17): 43294335.

Gholipoor F, Rashidi A (2008) Factors Affecting the Satisfaction of Tourists in Iran, 1-12. Retrieved from http://www.marketingarticles.ir.

Hazar Jaberi J, Najafi MM (2012) Sociological study of the factors affecting the development of tourism in Iran (with the approach of attracting foreign tourists). Geography and Environmental Planning 23(3): 133-146.

Jabari A, Gholami M, Kavousi Z, ChamanPara P (2016) The Role of Demographic Variables on the Viewpoint of Medical Tourists Regarding the Quality of Services of Hospitals. Quarterly Journal of Hospitals 15(3): 95-102.

Kotler BM (1999) Marketing for Hospitality and Tourism (2nd ed), ISBN: 0130136980. USA: Prentice Hall PTR.

Lopes SDF (2011) Destination image: origins, developments and implications. PASOS 9(2): 305-315. Retrieved from http://www.pasosonline.org.

Mellina FKM, Aballe AFA (2013) Satisfaction on tourist destinations in Davao Del Sur. International Journal of Accounting and Business Management 1(2):7-17. Retrieved from http://www.watchpub/ijabm/index.htm.

Oliveira B (2011) Determinantes de la satisfaccion del tourista, un studio en la ciudad de Guaruja-Brasil. [Determinants of tourist satisfaction, a study in the city of GuarujaBrazil]. Estudiosy Perspectivas en Turismo 20(1): 229-242.

Pearce LP (2005) Tourist Behaviour: Themes and Conceptual Schemes. Clevedon Hall England: Channel View Publications.

Perovic D, Stanovcic T, Moric I, Pekovic S (2012) What socio-demographic characteristics do influence the level of tourist's satisfaction in Montenegro? Empirical analysis. Journal of Tourism 14: 5-10.

Schofield P, Thompson K (2007) Visitor motivation, satisfaction and behavioural intention: the 2005 Naadam Festival, Ulaanbaatar. International Journal of Tourism Research 9: 329-344. Retrieved from http://www.interscience.wiley.com

The Heritage, Handicrafts and Tourism Organization of Ardebil (2016). Tourism Maps and Reports.

Tsiotsou R, Vasiotio E (2006) Using Demographic and Leisure Activities to Predict Satisfaction with Tourism Services in Greece. Journal of Hospitality \& Leisure Marketing 14(2): 69-82. Retrieved from http://www.haworthpress.com.

WTTC: World Travel \& Tourism Council (2013) Available at https://www.wttc.org/. 
Yoon Y, Uysa M (2003) An examination of the effects of motivation and satisfaction on destination loyalty: a structural model. Tourism Management 26(1): 45-46.

Zangi Abadi A, Mohammadi J, Zinkabash D (2006) Internal market analysis of Isfahan city. Journal of Geography and Development 4(8): 131-156.

Zainli B, Goujali S (2015) Assessing the Satisfaction of Tourists from the Performance of the Services of beach vacation rental suites: A comparative analysis according to Social Demographic Characteristics, the First National Tourism Conference, National Capital, Future Perspective, Isfahan.

Zeinali B, Jafarpour M, Hessam A, Shojaeivand B, Zolghadr H (2014) Tourists' satisfaction with and loyalty to shopping experience: a socio-demograhic analysis (2014). International Journal of Academic Research in Business and Social Sciences 4(6): 67-84. 
